\title{
ПЛЕМИЋИ НИКОЛИЋ ОД РУДНЕ. ПОРОДИЧНА ИСТОРИЈА У ЈЕДНОМ ДОКУМЕНТУ ИЗ ЗБИРКЕ НАРОДНОГ МУЗЕЈА БАНАТА У ТЕМИШВАРУ ${ }^{3}$
}

Племићка лоза Николић од Рудне била је једна од најистакнутијих српских породица у Угарској. Историја ове племићке породице је у великој мери непозната широј јавности, јер јој није била посвећена нека већа пажња у историографији. Постојећи докуменат, којег је написао један члан породице Николић, намењен је усвојеном сину барона Михајла Николића, односно Јовану Тирфелдеру. Докуменат је драгоцен извор података за породичну историју. Написан на немачком језику, докуменат се датира у првим деценијама 20. века. Обухвата шест листа и данас се налази у добро очуваном стању. Регистрован је у документарном фонду Историјског одељења, у оквиру Народног Музеја Баната у Темишвару. Докуменат обухвата 5 кратких поглавља, како следи: 1. Општи подаци о Србима у Угарској, 2. Извори у вези са историјом наше породице, 3. Презиме наше породице и начин како је оно написано, 4. Историја породице и 5. Запажања о употреби генеалошке табеле. Оригинални породични документи изгорели су у пожару који је задесио Рудну током Револуције 1848-1849. године. Због тога коришћени су други извори како би се написао овај докуменат, нпр. Национални Архив Угарске у Будимпешти или Архив Тамишке жупаније. Кратка породична историја, која обухвата до сада необјављене податке, представља најзначајнији део овога документа и уједно и нашега чланка. Други део чланка посвећен је барону Федору Николићу од Рудне. Реч је о најзначајнијем члану породице и једном од најугледнијих Банаћана друге половине 19. века. Као посланик, представљао је разне банатске округе у Угарском парламенту. Био је цивилни гувернер Босне и Херцеговине

\footnotetext{
11markovzoran@yahoo.com,cipi_gl@yahoo.com

${ }^{2}$ Рад је настао у оквиру пројекта Истраживање културе и историје Срба у Румунији који спроводи Ценатар за научна истраживања културе Срба у Румунији при Савезу Срба у Румунији.

3 Варијанту овог рада објавили смо 2010. године, на румунском језику, у часопису темишварског музеја Analele Banatului, S.N, Arheologie-Istorie, br. 18 [Марков, Главан, 2010: 173-183]. За разлику од поменутог чланка, где смо укратко описали најбитнија два поглавља, овај рад обухвата целокупни текст документа, у преводу на српском језику. Имајући у виду да су нам протеклих година многобројни историчари, истраживачи, чак и потомци племићке породице, тражили објављивање целог документа и превод текста на српском језику, користимо ову прилику да након једне деценије испунимо дато обећање.
} 
(1882-1886). Такође, био је председник разних друштава и предузећа у Банату и Угарској. Одликован је многобројним орденима и медаљама.

Кључне речи: породица Николић, Рудна, барон Федор Николић, збирка Народног Музеја Баната у Темишвару.

Племићка лоза Николић (мађ. Nicolics; рум. Nicolici) од Рудне 4 била је једна од најистакнутијих српских породица у Угарској. Својом политичком активношћу, а нарочито импресивним економским утицајем, ова племићка породица свакако заслужује своје место у страницама посвећеним модерној историји Баната.

Почеци ове племићке лозе су релативно непознати широј јавности и доста се слабо појављују у литератури. Подаци о Николићима су у главном приказани у форми кратких историјата, тако се појављују код мађарских историчара са почетка 20. века [Лендвај, 1905: 139-142; Боровски, 1913: 548]. Послератна историографија не доноси нажалост нове и кључне информације за боље упознавање ове племићке породице: српски историчари је у главном повезују са династијом Обреновић и приказују живот и активност последњих Николића [Миланков, 2001: 95-112], док је у румунској историографији ова проблематика, до пре неколико година [Марков, Главан, 2010: 173-183], била потпуно непозната.

У овом историографском контексту, сматрамо да ће објављивање у српској литератури једнога документа из збирке Народног Музеја Баната у Темишвару допринети разјашњењу породичне историје Николића у првим вековима свог постојања. Докуменат приказује значајне и до сада непознате информације за прошлост ове племићке лозе, али је и веома вредан због чињенице да је рукопис приредио управо један од чланова породице Николић. Докуменат, написан на немачком језику и насловљен Geschichte unserer Familie (срп. Историја наше породице), чува се у архивском фонду Народног Музеја Баната у Темишвару у два примерака: у рукопису (инв. бр. 21.735) и прекуцаној копији (инв. бр. 21.734). О томе како је докуменат пристигао у музејску збирку, за сада су очувани подаци неконклудентни, једино се зна да потиче из старе музејске збирке. Регистрован је 30 јуна 1988. године у музејском фонду Историја, у оквиру Историјског одељења банатског музеја у Темишвару [ГМЗНМБТ, бр. 27, стр. 33].

Неизвесност око идентификације аутора текста произилази из чињенице да сачувани докуменат није датиран, нити потписан. На основу анализе текста, сматрамо да се аутор може идентификовати у особу Александра

\footnotetext{
${ }^{4}$ Рудна је сеоско насеље у оквиру општине Ђулвез, у Тамишкој жупанији, у румунском делу Баната. Налази се близу државне границе са Србијом и удаљено је око 40 км од Темишвара. Конак породице Николић или „Каштел” је данас у приватном власништву и налази се у доста лошем стању. Породична гробница Николића, удаљена неколико километара од конака, је запуштена и у оронулом стању.
} 
(Шандора) II Николића (1878-1926): „И мој отац Шандор продао је свој део Рудне 1873. године, а затим је у више наврата био члан парламента, десет година жупан и умро је 1897. године". Шандора II, сина барона Александра (Шандора) I Николића од Рудне (1825-1897), помиње Шаму Боровски [1913: 548] у свом раду и за њега пише да је године 1913. био државни секретар у оквиру Министарства Унутрашњих Послова Угарске, наиме био је секретар Председништва судске администрације. То је једини део текста који се односи на аутора, а имајући у виду да очувани докуменат не садржи нити један потпис, до појављивања неких нових података предлажемо да наш закључак око идентификације аутора у особу Александра (Шандора) II Николића морамо, бар за сада, гледати у својству једне радне хипотезе.

Што се тиче особе којој је докуменат намењен, исто према анализи самог текста може се закључити да је реч о Јовану, усвојеном сину барона Михајла Николића (1841-1916). Реч је о Јовану Тирфелдеру, чија је усвојеност потврђена краљевском сагласношћу 1905. године [Боровски, 1913: 548]. Јован Тирфелдер је са племићким предикатом од Обренов (Обреновски) постао аустријски барон („Твој деда Јован оженио се Јелисаветом, ћерком српског кнеза Милоша Обреновића. Имао је петоро синова, од којих су Младен и Милан умрли у детињству, а Милош у одраслим годинама. Федор је био пет година цивилни гувернер Босне, тајни саветник, а затим твој отац Михајло.”).

На основу анализе самог текста може се одредити да је докуменат написан почетком 20. века, али после 1903. године, имајући у виду да се аутор односи на већ бившу српску краљевску лозу Обреновића („Из табеле видећеш твој степен сродства са бившом краљевском лозом, као и двоструко сродство са породицом Бајић").

Враћајући се самом документу, Историја наме породище из збирке Народног Музеја Баната у Темишвару чува се у документарном фонду Историјског одељења музејске институције и налази се у добро очуваном стању. Докуменат размера 36,1 х 22,4 см састоји се од 6 листа и написан је на немачком језику. У музејској збирци, као што је већ наведено, чува се и прекуцана копија документа, која се такође налази у веома добром стању очуваности. Филигрански папир на којем је текст написан производ је фабрике „Peterfalva Papirgyar”, док је прекуцана варијанта урађена на папиру са назнаком „Remington Papier”.

Докуменат обухвата 5 кратких поглавља, како следи:

1. Општи подаци о Србима у Угарској, 2. Извори у вези са историјом наше породице 3. Презиме наше породице и начин како је написано, 4. Историја наше породице и 5 . Запажања о употреби генеалошке табеле.

На крају текста аутор објашњава знакове који се јављују у раду.

Посебно важна за схватање породичне прошлости јесу поглавља бр. 2 и нарочито бр. 4. Друго поглавље текста обухвата опис архивске грађе коју 
je аутор користио за израду овог рада, док четврто поглавље представља породичну историју Николића почевши од додељеног племства, 1694. године од стране аустријског цара Леополда, и завршава се бароном Михајлом Николићем, који је преминуо 1916. године.

Битно је напоменути да се у тексту, и то у више наврата, говори о генеалошкој табели која се тада налазила у наставку постојећег документа. Нажалост, у музејску збирку је регистрован једино докуменат, без поменутог анекса. За графичку обраду родослова Николића од Рудне користили смо Лендвајову табелу [1905: 141]. Треба напоменути чињеницу да подаци из Лендвајовог родослова се благо разликују од породичног документа. Примећује се диспаритет у вези неких година и датума, али свеукупно може се рећи да Лендвајов родослов се поклапа у главном са породичном листом.

У наставку прилажемо целокупни текст документа, у преводу на српском језику:

\section{Историја наше породице}

\section{I. Општи подаци о Србима у Угарској}

У јужним деловима Мађарске и Славоније били су насељени још у средњем веку. Напредовањем Турака у 14. веку, Срби који су живели јужно од Дунава и Саве потиснути су на север.

Под краљем Жигмундом Луксембуршким, који је касније постао римски цар, одвијала се 1404. године прва велика сеоба. Онда су се многобројни Срби преселили из јужних подунавских области у Пештанску жупанију и населили се у Пешти, Будиму и околини, наиме у Сентандреји и на острву Чепел.

У наредним периодима Срби су и даље долазили у мањим или већим групама. На пример Павле Кинижи, који је 1482. године победио Турке, населио је око 40.000 Срба у Јужној Угарској.

Године 1692. одвила се највећа сеоба. Један цео народ, могло би се рећи, дошао је из Старе Србије под руководством патријарха Арсенија Чарнојевића. Гостољубиво их је примио Леополд I, који им је доделио привилегије, наиме у Бачкој области, у Банату, у област Сегедина и Арада.

У почетку се ово насељавање Срба сматрало привременим. У документу који је издао Леополд I, каже се да ће Срби бити заштићени као гости и да се нада да ће обједињене снаге хришћанства успети да протерају Турке из Европе, омогућавајући тако Србима повратак у стару домовину. С обзиром на то да је овај покушај пропао, насељавање Срба у Угарској постало је дефинитивно. 


\section{II. Извори у вези са историјом наше породице}

Оригинални документи из пре-револуционарног периода изгорели су 1848. године у породичној кући код Рудне. Али постоји велики број података, посебно у архивима, који нам омогућавају да реконструишемо историју наше породице. Најважнији су:

1. Напомене у Краљевским Књигама (Libri Regii) из Државног Архива у Будимпешти и оригинални сродни документи, концепти, прилози итд. Од тих докумената позната ми је потврда оплемењивања Јована Николића из 1783. године, као и донација домена Рудна из 1804. године.

2. Записник племића Пештанске жупаније, у којем је очувано неколико бележака, укупно 29 података који се односе на различите чланове породице између 1694. и 1810. године. То се посебно односи на случајеве када је један од чланова породице затражио од жупаније потврду која би сведочила о његовој племићкој титули. Племићи без имовине морали су имати такву потврду ако су желели да остваре своја права и привилегије везане за племићку титулу. Ако је неко желео да се насели у другој жупанији, морао је да саопшти своју племићку титулу, како би избегао било какву невољу. У том контексту, потврда из матичног округа била је апсолутно неопходна. Ово такође објашњава мноштво сачуваних података.

3. У архиву Тамишке жупаније постоји генеалошка табела коју су користили Манојло и Каритон Николић 1810. године, како би доказали њихову племићку титулу. Табела се простире током целог 18. века.

4. Тестамент твог прадеде, Јована Николића, из 1828. године, чију стару копију имам, друге документе и писма, која представљају у главном судску документацију и која су избегла горе поменути пожар и сада се налазе у мом поседу.

5. Разна историјска дела и монографије, научни радови и новински чланци.

Н. Б. Нисмо видели ниједну копију или концепт првог писма о оплемењивању. О садржају сазнао сам из посредних извора. Постоји могућност да ће једнога дана изаћи на видело из неког архива.

\section{III. Презиме наше породице и начин како је написано}

Прво писмо о оплемењивању издато је 1694. године за тројицу браће Манојла, Петра и Славона Николу. Током 18. века ушло је у употребу име Никола односно Николић или Никола алијас Николић и латинизована варијанта Nicolics. Од 1783. године једино Nicolics и писано само са „„”. Ти знаш да су српска породична имена настала од крштеног имена и завршног слога „цћ” (мађ. ,ісs”), који указује порекло од породичног предака, првог 
носиоца дотичног крштеног имена. Тако се Николић односи на потомке једног претка, који се звао Никола (Николаус на немачком језику). У древним временима, крсно име претка често се користило као породично име, а касније је редовно додаван деминутивни ангтропонимски суфикс -uћ.

\section{IV. Историја наше породице}

Краљ Леополд I је 26 марта 1694. године доделио браћи Манојлу, Петру и Славону Николи, као и Манојловој супрузи Ани, мађарску племићку титулу посредством једног „Армала” или оплемењивачког писма са грбом. Објављено је исте године у скупштини Пештанске жупаније. Потомци тројице браће живели су у Пешти, Будиму, Рацком Ковину, Сентандреји, а неки су стигли до Лугожа и Чакова. Тако на пример, помињу се из Манојлове лозе у Пештанском записнику племства следећи:

Манојло, 1694, 1719, 1730. године.

1. Манојлов син Никола (Пешта) 1730, 1754. год. и његови синови: Михајло (Пешта) 1754, 1774. год; Манојло (Пешта) 1754. год; Антоније (Пешта) 1754. год.

2. Теодор (Будим) 1730, 1754. год. и његов син Нестор 1754, 1762 , 1771. године.

3. Ђорђе (Рацки Ковин) 1730, 1754. год. и његов син Јован 1754, 1762 , 1771. год., са својим сином Стефаном (Сентандреја) 1789. год.

4. Михајло (Лугож) 1730, 1754. год. и његов син Ђорђе.

Даље, по Петровој линији:

Петар 1694, 1719, 1730. год. - његов син Никола са сином Манојлом 1754 , као и своји праунуци Јован (Осијек) 1778, 1782, 1783. год. Гргур 1801, Каритон и Манојло (Чаково) 1810.

На крају, по Славоновој линији:

Славон 1694, 1719, 1730. год - његови синови Теодор 1754, 1771. год. и Теодосије (Пешта) 1754, 1770, 1775 . год, као и унук од првога сина, Теодосије (Сентандреја) са својим сином Андреасом 1802, 1804. год.

Ђopђе, Петров син, добио је надимак Хаџи. Тако су названи они који су посетили Свети Гроб у Јерусалиму, што је у то време било много теже него данас и због тога су их потомци веома ценили; ова чињеница истакнута је у документима потврде племићке титуле 1783 . године - Ђорђев син био је

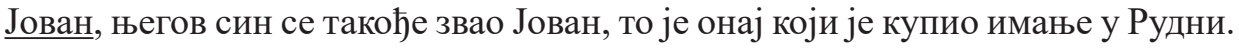

Овог Јована Николића или како су га звали у документима тога времена, Никола алијас Николић, налазимо га почев од 1772. године у Осијеку, у Славонији; овде је трговао и првенствено се бавио образованим системом, који је организован широм земље у складу са законом Ratio educationis publicae царице Марије Терезије.

У Банату 1782. године, односно у жупанијама Тамиш и Торонтал, успостављене након коначног протеривања Турака, продата су бројна имања и 
домени од стране пореских власти. Пошто је тада само властела имала право поседовања некретнине, ако је неко без племићке титуле желео купити имање, морао је прво да добије племство.

Јован Николић је те године купио заједно са својим тастом Тодором Јанковићем од Миријева имање Рудна, за цену од 52.028 гулдена и 22 3/4 крајцера. Пошто је пореска управа оптерећивала куповину имања због неприхватљивог доказа око племићке титуле, морао је да докаже своје племство путем такозваног Processus productionalis. Овај начин потврђивања предвиђен је у такозваним Краљевским Књигама. Прочитао сам све оригиналне документе. Као резултат дотичног поступка, цар Јосиф II је 18 априла 1783. године потврдио актом бр. 3400/1783 његову стару племићку титулу.

Јован Николић је касније платио откуп свом сараднику Јанковићу и тако постао једини власним имања Рудна. Пошто није имао деце, усвојио је једног младог човека: Јована Белчића. Отац овога младића био је грађанин Земуна, а мајка, која се звала Марта, рођена је у Иригу у Славонији 1747. године. Младић је такође рођен у Земуну 1776. године. Овај усвојени син старог Николића је предак свима нама. Као што видиш, ми нисмо потомци старог Николића, ми смо заправо Белчићи.

На захтев старог Јована Николића, краљ Фрањо I одобрио је 14 августа 1804. године актом бр. 8113/1804 донацију имања Рудна „од нашег, вернога Јована Николића, саветника апелационих судова, Витеза златне мамузе, дворског столника, његовом усвојеном сину Јовану Белчићу, који ће од сада носити име Николић”. Овим актом одобрено је усвајање, пренос племићке титуле и грба, као и одрицање од имена Белчић, које је до тада носио.

Међу заслугама старог Николића, које произилазе из документа донације и његових анекса, помињем:

1. Активно је учествовао у јавном и друштвеном животу Торонталске жупаније; године 1792. учествује у својству делегата на радовима Дијете у Пресбургу 5 где се одржало крунисање цара Фрање.

Овом приликом одликован је орденом Витеза златне мамузе (ово је старо мађарско специфично одликовање које је дато искључиво током церемоније крунисања).

Овде треба напоменути да је имао и наслов Aulae Regiae Familiaris, што је једнако са дворским столником. Такође је био саветник апелационих судова Торонталске, Тамишке и Сремске жупаније. У то време ово није била званична функција, већ племићка канцеларија за аристократе, који су имали добро знање у области јуриспруденције.

2. За војне потребе ратовања са Турцима 1788. и 1789. године и за оне са Французима 1794, 1796, 1800. и 1801. године, поклонио је велике суме новца, природних производа и житарица.

\footnotetext{
${ }^{5}$ Данас Братислава, главни и највећи град Словачке.
} 
3. У домену образовања имао је велике заслуге у Осијеку, тако да је 1787. године, када је већ био власник Рудне, постављен на челу управе српских школа у Осијеку.

4. Године 1810. постао је ко-администратор Управе Српског Националног Фонда.

5. Између 1772. и 1782. године тргује и одржава везе са фабрикама перзијске вуне у Бечу и Линцу и оснива такве радње у земљи.

Овим се прича старог Николића завршава и почиње историја наше породице. Није ми познато шта се догодило са осталим Николићима, којих је крајем 18. века било још много, као што можеш видети и у табели. Чињеница да су остали једноставни армалисти, односно племићи без предиката, показује да је свест о припадности племићкој породици временом избледела у одсуству предиката, који би их тако разликовао.

У Пештанском записнику, последњи подаци који се на њих односе, датирају из 1810. године.

Године 1811, Манојло и Каритон Николић дошли су у Чаково и доказали, како би им признали племићку титулу, сродство са старим Јованом Николићем од Рудне. Након тог датума нема више података о њима.

Јован Белчић, од 1804. Николић, је тако постао власник Рудне и предак већине банатских племићких породица, као што можеш видети у табели.

Његова прва супруга била је Јелисавета, ћерка Анастаса и Марије Карамат од Земуна. Са овом првом супругом добио је сина Јована (твога деду) и три ћерке. Марија се удала за Јована Атанасијевића од Валеапаја. Јелисавета удала се за барона Стефана Дуку од Кадара, док се Софија удала за Константина Манасија од Ходоња. Његова друга супруга била је Алојзија, ћерка Петра Текелије од Кевермеша и Катарине Соплонцој од Тивадара ${ }^{6}$. Са овом другом супругом је имао два сина: Петра и Шандора (мога оца).

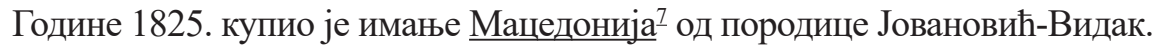
Умро је 1828. године.

Према горе наведеном тестаменту, његову имовину наследила су његова три сина и то Јован Мацедонију, а Петар и Шандор Рудну, како следи:

Рудна се тада састојавала од 5780 јутара са 48 1/2 сесија, то јест парцела сељака, док Мацедонија од 2000 јутара са 62 1/2 сесија. Да би се имовина правилно поделила, одређено је да Јован добије још 600 јутара од имања Рудне, док је од имања Мацедоније примио 23 1/8 сесија, то јест заједнички део који се налази западно од доменијалних вртова, заједно са 68 сељака који су се ту населили, тако да су дотични сељаци морали извршавати услуге велепоседницима Рудне.

\footnotetext{
${ }^{6}$ Maђ. Katharina Szaplonczay von Tivadar.

${ }^{7}$ Мацедонија је мало сеоско насеље у оквиру градске општине Чаково, у Тимишком округу, у румунском делу Баната.
} 
Твој деда Јован оженио се Јелисаветом, ћерком српског кнеза Милоша Обреновића. Имао је петоро синова, од којих су Младен и Милан умрли у детињству, а Милош у одраслим годинама. Федор је био пет година цивилни гувернер Босне, тајни саветник, а затим твој отац Михајло.

Године 1854. додељена му је аустријска баронска титула.

Умро је 1880. године.

Што се тиче браће твога деде, можда ће те занимати чињеница да је Петар продао свој део Рудне 1875. године свом синовцу, а затим се повукао у Житиште где је и преминуо 1878. године.

Његов син Иван умро је без потомства.

И мој отац Шандор продао је свој део Рудне 1873. године, а затим је у више наврата био члан парламента, десет година жупан и умро је 1897. године.

Што се тиче сестара твога деде и њихових потомака, имаћеш бољу слику пратећи табелу, а овде остављам списак са именима која носе или су носили и чији је заједнички предак Јован Николић и који су у закључку твоји крвни сродници:

Николић од Рудне

Барон Николић од Рудне

Барон Николић од Обренов

Гроф Хардег ${ }^{8}$

Вих од Ројта 9

Атанасијевић од Валеапаја

Бајић од Варадије

Барон Бајић од Варадије

Барон Траутенберг

Барон Талиан од Визека ${ }^{10}$

Весели $^{11}$

Барон Дука

Патијански од Висаkа ${ }^{12}$

Ронај од Кишсомбора ${ }^{13}$

Чарнојевић од Маче и Малог Оросина ${ }^{14}$

\footnotetext{
${ }^{8}$ Hем. Graf Hardegg.

${ }^{9}$ Hем. Wich von der Reuth.

${ }^{10}$ Maђ). Tallián von Vizek.

${ }^{11}$ Maђ. Weszely.

${ }^{12}$ Maђ. Pattyanszky von Viszág.

${ }^{13}$ Maђ. Rónay von Kis-Zombor.

${ }^{14}$ Данас Руско Село, Кикинда, Севернобанатски округ.
} 


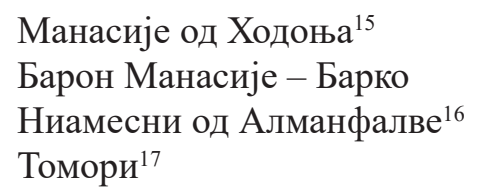

Такође сам припремио и другу табелу за породицу Обреновић и све њене потомке. Из табеле видећеш твој степен сродства са бившом краљевском лозом, као и двоструко сродство са породицом Бајић.

Историју породице Обреновић - ако ти је до сада није већ позната можеш је укратко пронаћи у Gothaischer Hofkalender, а детаљније у лексикону за разговор. Ја имам Brockhaus, а вероватно је и у оном другом једнако добро описана.

\section{V. Запажања о употреби генеалошке табеле}

Табеле су приказане у облику стабла и читају се одоздо према горе. Са доње стране јесу они најстарији, а горе су они млађи.

Како би обухватио велики број појединаца, урадио сам три табеле, наиме:

А. Од краја 17. до почетка 19. века и обухвата потомке тројице браће, која су стекла племићку титулу: Манојла, Петра и Славона - садржи 5 генерација.

Б. Од краја 18. века па до дан данас и обухвата све потомке Јована Белчића - садржи 6 генерација.

В. За породицу Обреновић и њене потомке - садржи 7 генерација.

Породице које су брачно повезане, првенствено су истакнуте црвеном бојом, а подизање у племићку хијерархију и други значајни подаци обележени су плавом бојом.

\section{Објашњење знакова}

$\mathrm{x}=$ Рођен

$+=$ Покојник

$\mathrm{X}=$ Ожењен са...

$\mathrm{X} 1)=$ Прва супруга или муж

$\mathrm{X} 2)=$ Друга супруга или муж

)( = Одвојени, разведени

$\mathrm{Y}$ случају бракова између рођака знак X повезује два правоугаоника која се налазе један поред другог."

\footnotetext{
${ }^{15}$ Maђ. Manaszy von Hodony.

${ }^{16}$ Maђ. Niamessny von Almánfalva.

${ }^{17}$ Maђ). Tömöry.
} 
У наставку нашег рада навешћемо и неколико података која се не појављују у наведеном документу, али која су веома значајна у нашем покушају објављивања што детаљније историје племића Николић од Рудне.

Породица Николић од Рудне била је православне вероисповести. Племићки грб Николића, издат заједно са племићком дипломом, има следећи састав: у плавом пољу појављује се златни крунисани лав са двоструким репом, стојећи окренут на десну страну; у десној подигнутој шапи држи сабљу, док леву шапу претећи пружа напред. Што се тиче крунског дела грба: појављује се бели голуб, окренут ка десној страни, спреман за полет, са маслиновом гранчицом у кљуну. Хермелин: златно-плаве и сребрно-плаве боје.

На баронском грбу златни лав не носи круну, али за разлику од пређашњег племићког грба, сада се у доњој страни појављује латински мото: „Virtutum Nexu” (срп. „Врлином повезани”) [Лендвај, 1905: 142].

Од свих чланова племићке породице Николић од Рудне, један заслужује посебну пажњу: барон Федор Николић (1836-1903). Велика политичка личност у другој половини 19. века, барон Федор Николић од Рудне остаће запамћен толико у српској банатској историографији, колико и у аустроугарским аналима. Федор Николић рођен је у Темишвару 7 јуна 1836, као други син Јована Николића (1810-1880) и Јелисавете Обреновић (1814-1848), ћерке српског кнеза Милоша Обреновића. Федор је похађао средњу школу у Темишвару и Бечу, да би после тога завршио правни факултет Универзитета у Грацу. Након дипломирања, млади барон Федор Николић враћа се у земљу и ради у кратком временском периоду као чиновник у канцеларији грофа Коронинија.

Године 1860. изабран је за посланика у Угарском парламенту као представник округа Пардањ ${ }^{18}$, а од 1865 . године и округа Жомбоља, али је одустао од овог мандата 1867. године. Након тога, 27 јуна 1862. године, положио је адвокатски испит; адвокатску праксу је одвијао под руководством темишварског адвоката вон Сулнока [Temeswarer Zeitung, год. 52, бр. 49, 1 март 1903, стр. 1-3].

После атентата на свог рођака, кнеза Михајла Обреновића, у Београду 10 маја 1868, барон Федор Николић заједно са осталим потомцима кнежевих сестара (барони Бајић и барон Михајло Николић од Рудне) стекли су велику имовину након договора са удовицом кнеза Михајла Обреновића, односно са кнегињом Аренберг, рођена као грофица од Хуљади [Temeswarer Zeitung, год. 52, бр. 49, 1 март 1903, стр. 1-3].

Барон Федор Николић оженио се 18 маја 1879. оперском певачицом Вилхелмином Хирш ${ }^{19}$, позната због великог талента и лепоте, жена богатог образовања [Temeswarer Zeitung, год. 52, бр. 49, 1 март 1903, стр. 1-3].

\footnotetext{
18 Данас Међа, Житиште, Средњобанатски округ.

${ }^{19}$ Heм. Wilhelmina Hirsch.
} 
Године 1880. барон се враћа политичкој сцени и под надлежност Министарства Спољних Послова Аустроугарске, врши неколико значајнијих дипломатских мисија у балтичким земљама.

Након успостављања мира у Босни и Херцеговини, угарски министар финансија Бењамин де Калај изабрао је барона Федора Николића за цивилног гувернера покрајине. Дана 15 јула 1882, барон Николић постављен је званично за цивилног гувернера Босне и Херцеговине, имајући и чин тајног саветника са титулом „Екселенција”. Док је служио у Босни, 10 фебруара 1886 , Федор је добио од угарског краља и титулу угарског барона [Миланков, 2001: 102], пошто је већ имао од 1854. и аустријску баронску титулу. Остао је на том положају све до 1886. године, када је именован за члана Дома Магната.

Две године касније, 1888, учествује на парламентарним изборима у Великој Кикинди, са либералним програмом, и добија једногласну подршку Кикинђана. Представља тај округ у парламенту током три мандата.

Године 1890. барон Федор Николић именован је за краљевског комесара на Српском црквено-народном Сабору, позицију коју је задржао све до 1902. године. У својству краљевског комесара имао је посебне заслуге што се тиче развитка српске црквене аутономије и добрих односа између цркве и државе.

Дана 22 децембра 1894, у месечној седници Историјског и археолошког друштва Јужне Угарске у Темишвару, забележена је донација барона Федора и Михајла Николића темишварском музеју [TRET, 1894: 112]. Према донационом писму из 13 новембра 1894. [ИАНМБТ, фонд Историјско и археолошко музејско друштво у Темишвару, досије новембар/1894], у музејском фонду улази драгоцена нумизматичка збирка, састављена од: 29 златника, 297 сребрних новчића и око 190 бронзаних новчића [TRET, 1895: 124].

Међу титулама, орденима и почасних функција, навешћемо оне најзначајније: Барон Федор Николић од Рудне, велики земљопоседник; тајни саветник Његовог Величанства; члан Дома Магната Угарске; носилац ордена Гвоздене Круне; носилац Великог Крста српског Таковског ордена; краљевски комесар на Српском црквено-народном Сабору; цивилни гувернер (адлатус) Босне и Херцеговине; председник Штедионичарске Куће Темесер Аграр-Шпаркаса А. Г., од њеног оснивања; председник темишварског друштва Лојд, од његовог оснивања; председник Унгарише Ханделс А.Г. из Будимпеште; председник Института за осигурање војних служби; председник Парног млина из Велике Кикинде А.Г.; председник Фабрике шибица у Темишвару А.Г.; потпредседник бечког Друштва за животна осигурања и пензије; потпредседник Друштва за осигурање у Бечу итд. [Temeswarer Zeitung, год. 52, бр. 49, 1 март 1903, стр. 1-3].

У каснијим годинама посветио се његовим омиљеним плановима који укључују изградњу пловног канала између Дунава и Тисе, пројекат који би обухватио и Бегеј са Темишваром [Temeswarer Zeitung, год. 52, бр. 49, 1 март 1903, стр. 1-3]. 
Барон Федор Николић преминуо је 27 фебруара 1903. године у Рудни. На сахрану барона присуствовао је тадашњи епископ будимски Лукијан Богдановић, у својству администратора епархије темишварске [Миланков, 2001: 108].

Радници погребног предузећа „Сент Маргит” поставили су метални ковчег са посмртним остацима барона Федора Николића у Српску Цркву у Рудни. Црква је у унутрашњост била у потпуности прекривена црним текстилом, а све куће између конака и железничке станице специфично су декорисане у складу с жалосним догађајем. На сахрани је присуствовало 4.000 људи, укључујући овде и становнике Рудне са суседним селима. Баронови посмртни остаци сахрањени су у породичној гробници на имању у Рудни [Temeswarer Zeitung, год. 52, бр. 50, 3 март 1903, стр. 1-2].

\section{Литература}

Боровски, 1913: Samu Borovszky, Magyarország vármegyéi és városai, Torontál, Budapest.

Лендвај, 1905: Miklós Lendvai, Temes vármegye nemes családjai, III, Budapest/ Temesvár.

Марков, Главан, 2010: Zoran Marcov, Ciprian Glăvan, Istoria familiei Nikolics redată într-un document din colecția Muzeului Banatului, Cluj-Napoca: Analele Banatului, S.N., Arheologie-Istorie, XVIII, Editura Mega, 173-183.

Миланков, 2001: Владимир Миланков, Барон Федор Николић од Рудне, Нови Сад: Темишварски зборник, бр. 3, Матица српска, 95-112.

\section{Извори}

Историјски Архив Народног Музеја Баната у Темишвару (ИАНМБТ).

Генерални Музејски Записник Народног Музеја Баната у Темишвару (ГМЗНМБТ).

\section{Периодика}

Temeswarer Zeitung, Темишвар (1903).

TRET - Történelmi és Régészeti Ėrtesitő, Темишвар (1894, 1895).

\section{Порекло коришћених илустрација}

1. Прва страница рукописа Историја наше породице (збирка Народног Музеја Баната у Темишвару).

2. Баронски грб породице Николић од Рудне (Лендвај, 1905).

3. Портрет барона Федора Николића (Боровски, 1913). 
4. Донационо писмо барона Федора и Михајла Николића из 13 новембра 1894. године (историјски архив Народног Музеја Баната у Темишвару).

5. Конак породице Николић у Рудни (Боровски, 1913).

6. Разгледница Рудне с почетка 20. века (https://gallery.hungaricana.hu).

\title{
THE NIKOLIĆ OF RUDNA NOBLES. THE HISTORY OF THE FAMILY IN A DOCUMENT FROM THE COLLECTION OF THE NATIONAL MUSEUM OF BANAT
}

\begin{abstract}
Summary
The family Nikolić of Rudna was one of the most important families of Serbian descent from Hungary. The history of this noble family is largely unknown, as it didn't receive much attention in the historiography. The present document was written by a member of the Nikolic family and addressed to the adopted son of baron Mihajlo Nikolić, Jovan Tirfelder. The document is an excellent information source about the history of the family.

The document was written in German in the first decades of the 20th century. It comprises six pages and nowadays it is preserved, in a good state of conservation, in the document collection of the History department of the National Museum of Banat from Timișoara. The document comprises five short chapters: 1. General data about the Serbians in Hungar, 2. Sources about the history of our family, 3. The name of our family and its notation, 4 . The history of our family end 5. Remarks regarding the use of the genealogical charts.

The original documents regarding the history of the family before 1848 were lost during a fire, which occurred in Rudna during the 1848-1849 revolution. That is why it was necessary to use other sources in order to write the present document: e.g.: National Archives of Hungary in Budapest or the Archives of the Timiș County. A short history of the family, which contains previously unpublished aspects, constitutes the most significant part of this document and of the present article.

Another part of the article is dedicated to the baron Fedor Nikolić of Rudna. He was the most important member of the family and a notability in Banat in the second half of the XIXth century. As a deputy, he represented various districts of Banat in the Hungarian parliament. He had an important position in the governing body of Bosnia and Herzegovina (1882-1886). Additionally he led several associations and commercial companies from Banat and Hungary and received various titles and medals.
\end{abstract}

Key words: Nikolić family, Rudna, baron Fedor Nikolić, National Museum of Banat Collection. 


\section{Прилози}

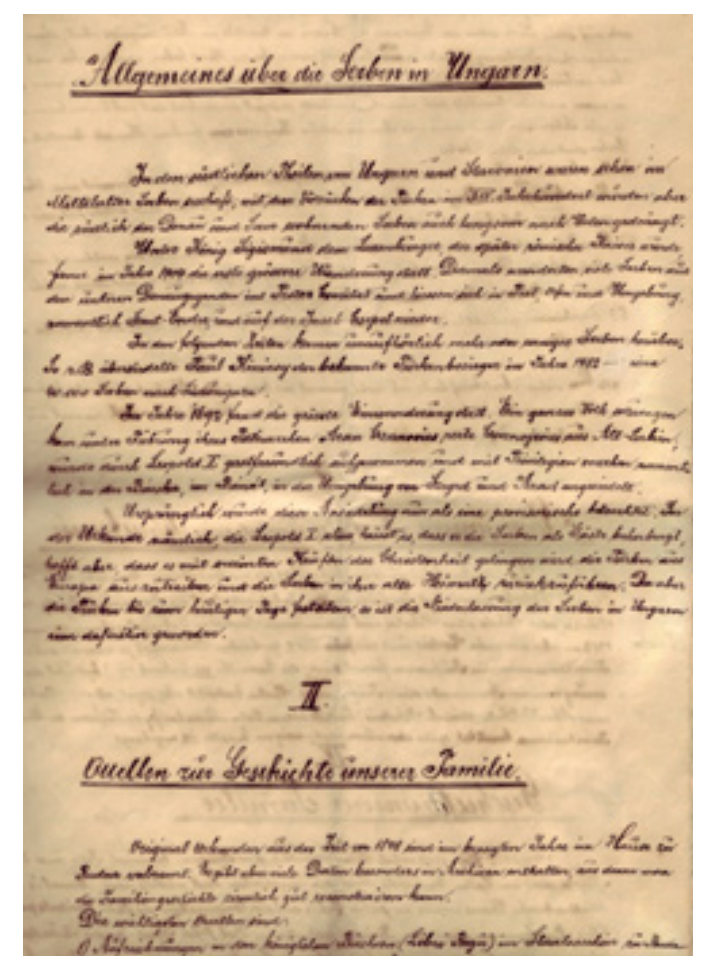

Прилог бр. 1 Прва страница рукописа Geschichte unserer Familie (срп. Историја наше породице)

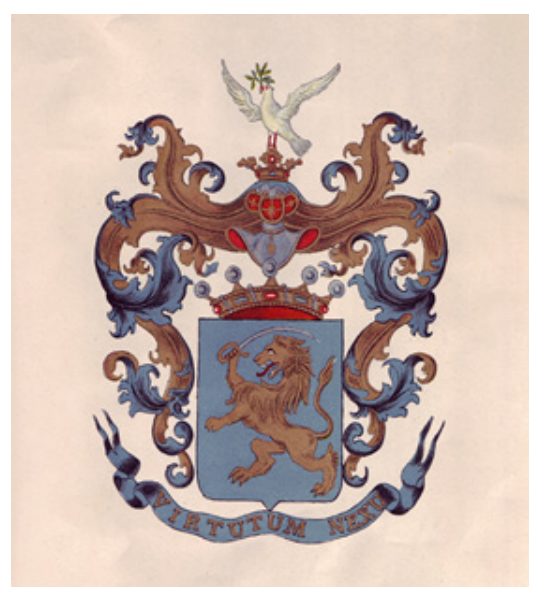

Прилог бр. 2: Баронски грб породице Николић од Рудне (друга половина 19. века) 


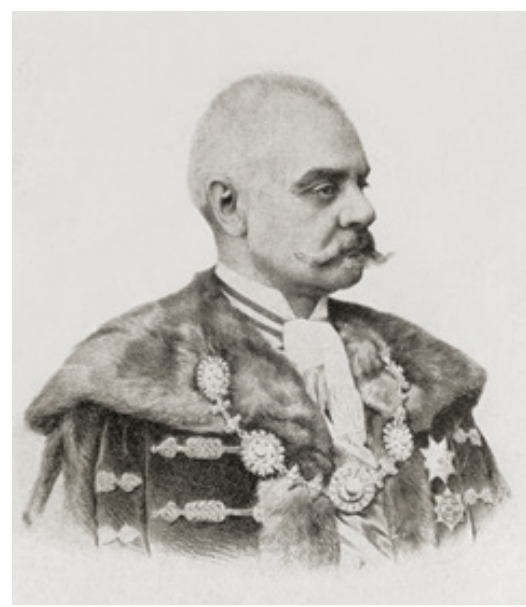

Прилог бр. 3: Портрет барона

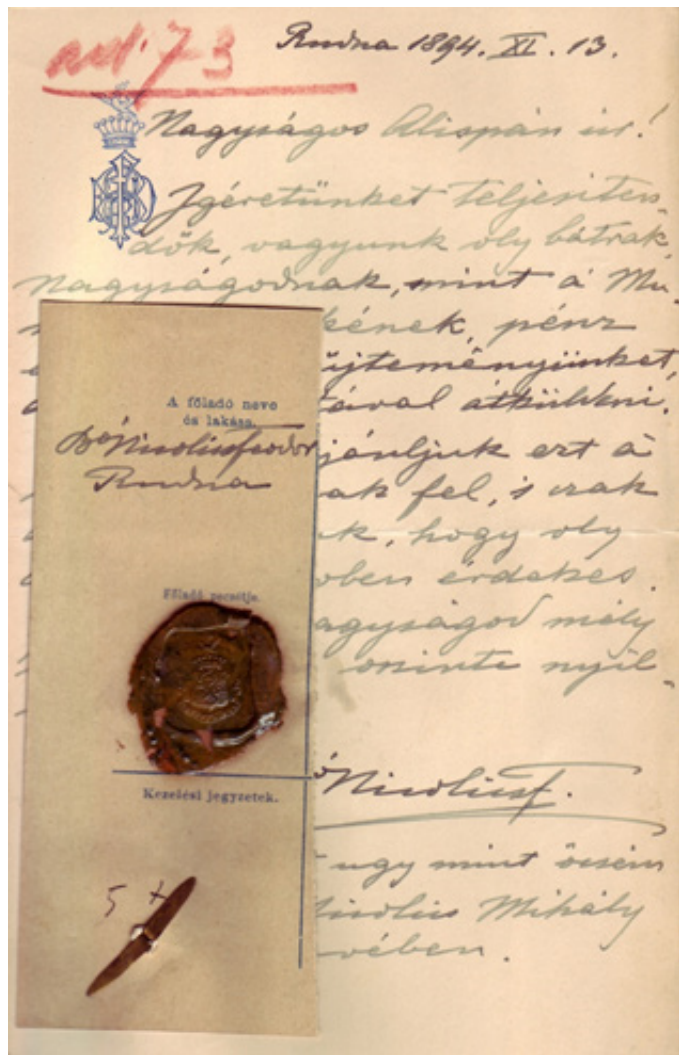

Прилог бр. 4: Писмо барона Федора и Михајла Николића из 13 новембра 1894. у вези са донацијом једне вредне нумизматичке збирке темишварском музеју. 


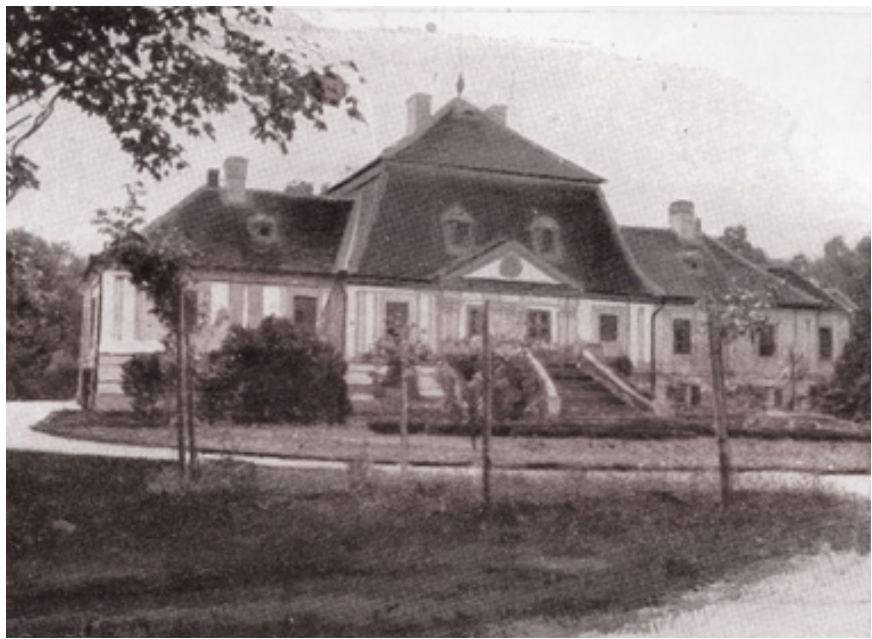

Прилог бр. 5: Конак или „Каштел” породице Николић у Рудни почетком 20. века

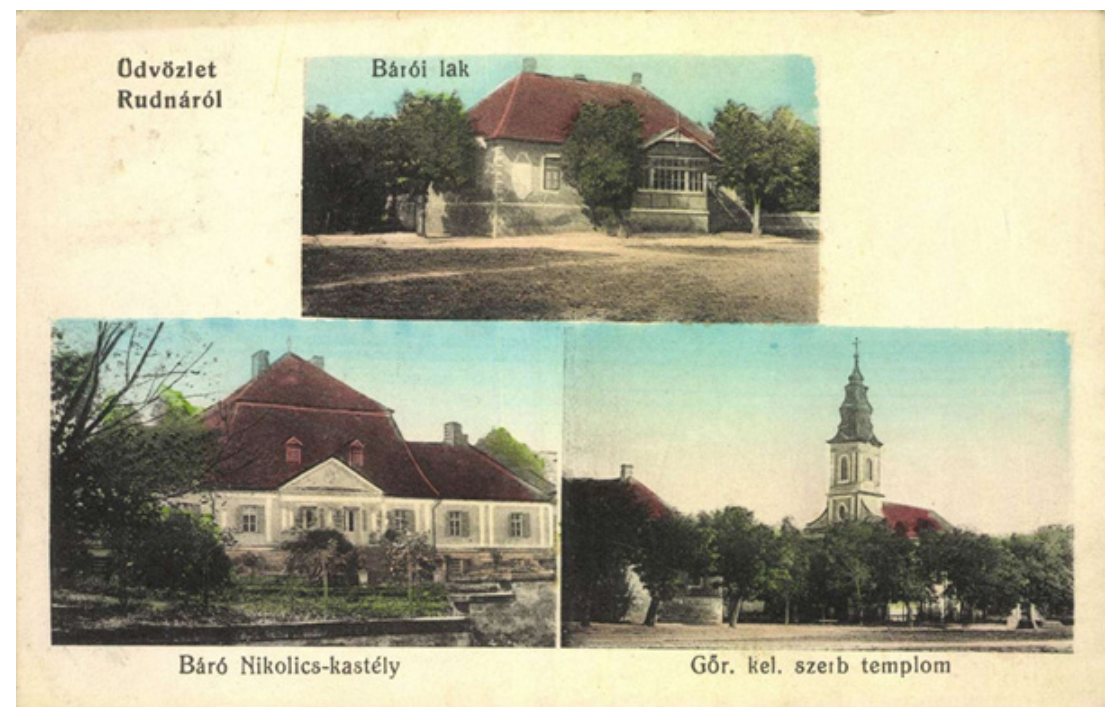

Прилог бр. 6: Разгледница Рудне с почетка 20. века баронска вила, конак и српска црква. 
Родослов паемиһке поролиие Никовиһ:

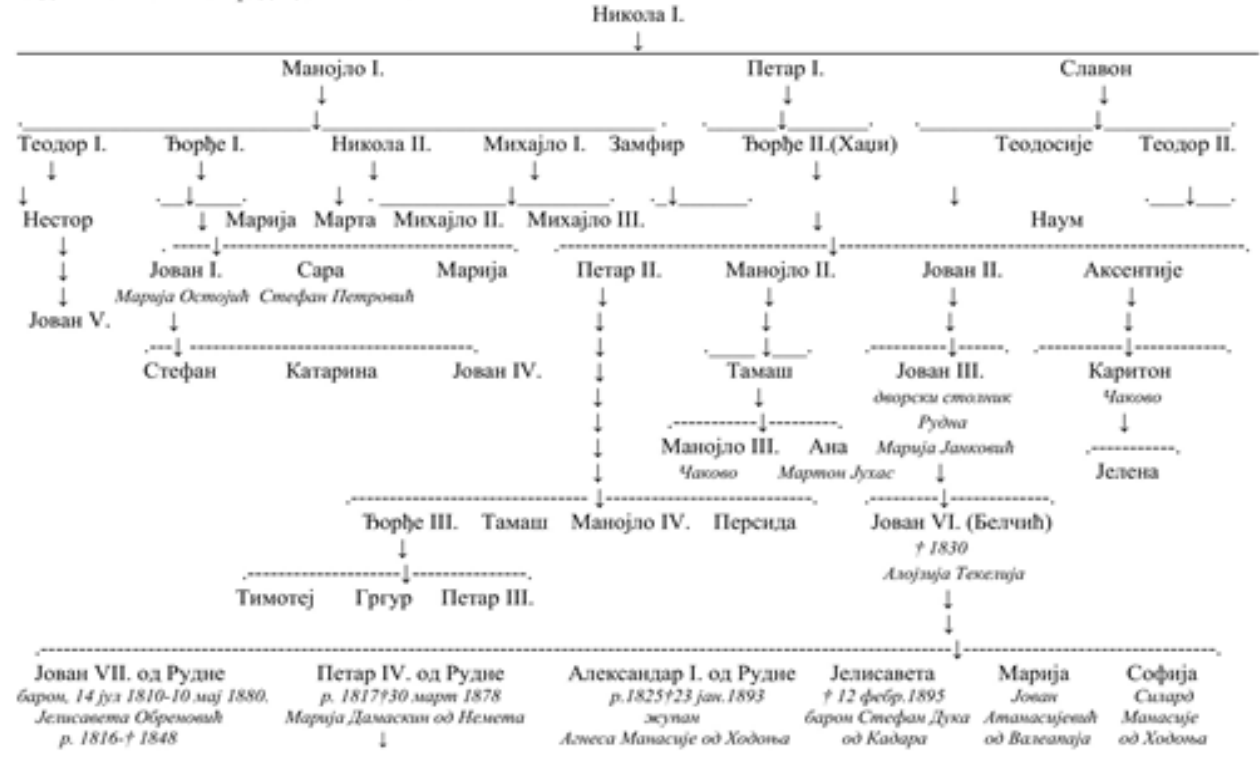

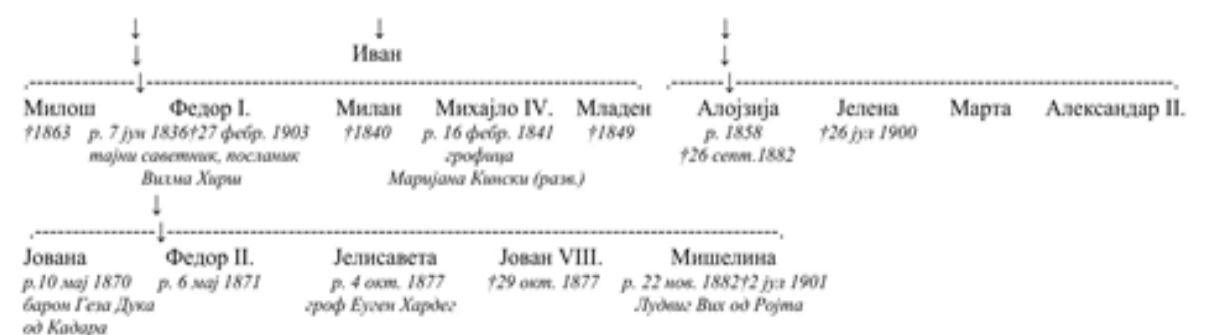

[Nendeaj, cmp. ISI, mav III] 